\title{
Participation of Host Cell Actin Filaments during Interaction of Trypomastigote Forms of Trypanosoma cruzi with Host Cells
}

\author{
Carlos Tadeu Fonseca Rosestolato ${ }^{1}$, Juliana da Matta Furniel Dutra ${ }^{2}$, Wanderley De Souza ${ }^{1,2}$, and Tecia \\ Maria Ulisses de Carvalho ${ }^{1,2^{*}}$ \\ ${ }^{1}$ Laboratório de Biologia Celular e Tecidual, Centro de Biociências e Biotecnologia, Universidade Estadual \\ do Norte Fluminense, Campos dos Goytacazes, Rio de Janeiro, RJ, Brasil and ${ }^{2}$ Laboratório de Ultraestrutura \\ Celular Hertha Meyer, Instituto de Biofísica Carlos Chagas Filho, Universidade Federal do Rio de Janeiro, Rio \\ de Janeiro, RJ, Brasil
}

\begin{abstract}
The involvement of actin filaments from the host cell on the process of invasion of trypomastigote forms of Trypanosma cruzi was analyzed in seven different cell lines. Prior incubation of all cell lines with cytochalasin D, under conditions which interfere with actin filaments, markedly inhibited parasite internalization and increased parasite attachment. Attached parasites were readily ingested following washing of the drug-treated cells. Cytochalasin treatment interfered with the distribution of actin filaments of the host cell as evaluated by visualization of the filaments using confocal laser scanning microscopy of cells incubated in the presence of FITCphalloidin. Concentration of actin filaments could be observed in most, but not all, parasites in the process of internalization. We also treated LLCMK 2 and macrophage cells with Jasplakinolide, a drug that stabilizes actin filaments, before interaction with the trypomastigote forms. This drug partially inhibits parasite invasion into the cells. Prior incubation of the host cells in the presence of colchicine, which interfere with microtubules, also inhibited parasite internalization into the cells.
\end{abstract}

Key words: Trypanosoma cruzi/cytoskeleton/actin/cytochalasin D/jasplakinolide/confocal microscopy

Trypanosoma cruzi is the causative agent of Chagas's disease, that affects millions of people in Latin America. It is an obligate intracellular parasite able to infect almost all nucleated cells through an endocytic process whereby an endocytic vacuole is initially formed. Enzymes released from the trypomastigote then start the disorganization and subsequent lysis of the membrane lining the endocytic vacuole. In the meantime, the parasite gradually changes into its amastigote form which after 24 hours begins to multiply in direct contact with the cytoplasm (Brener et al., 1973; Carvalho et al., 1989; Ley et al., 1990).

The molecular mechanism by which the trypomastigote form is recognized and internalized by host cells is still in debate. Evidence has accumulated to indicate that the interaction of $T$. cruzi trypomastigotes with host cells is mediated by specific molecules localized on the surface of both

\footnotetext{
*To whom correspondence should be addressed: Técia Maria Ulisses de Carvalho, Instituto de Biofísica Carlos Chagas Filho, UFRJ, CCS-Bloco G Ilha do Fundão, 21941-900, Rio de Janeiro, RJ-Brasil.

Tel: +55-21-2602364, Fax: +55-21-2808193

E-mail: tecia@biof.ufrj.br

Abbreviations: $\mathrm{M} \phi$, macrophage; $\mathrm{CytD}$, cytochalasin D.
}

cells (Andrews et al., 1995; Araujo-Jorge et al., 1992; Maria et al., 1982; Nogueira et al., 1976; Procopio et al., 1994). However, there is still some discussion regarding the involvement of host cell actin on the process of parasite internalization. Some studies report that treatment of host cells with cytochalasin B or D, drugs which interfere with actin filaments and inhibit the phagocytic process, inhibited the infection of the cells by the parasite (Barbosa et al., 1995; Meirelles et al., 1982). Others, however, show that the same treatment even increased parasite penetration (Procopio et al., 1994; Schenkman et al., 1991; Schenkman et al., 1992; Tardieux et al., 1994). Since these reports have been made based on experiments carried out under different experimental conditions we decided to re-analyze the effect of cytochalasin D (CytD) on the interaction of T. cruzi with 5 different host cells under well controlled conditions. Jasplakinolide, another drug that acts on actin filaments to stabilize them (Holzinger et al., 1997), was also used in LLCMK 2 and macrophage cells before the interaction process. We also analyzed the effect of colchicine, that affects microtubules, on the interaction process. In addition immu- 
nofluorescence microscopy was used to determine the distribution of actin filaments during the interaction process. We also used scanning electron microscopy to show the site of parasite entry in cells non treated and treated with cytochalasin D. The results obtained are described in this paper.

\section{Materials and Methods}

\section{Parasite}

The Y strain of Trypanosoma cruzi was used. The trypomastigote form was obtained from the supernatant of Vero cells previously infected as described previously (Carvalho et al., 1989).

\section{Host cells}

The following cell types were used: a) Resident peritoneal macrophages obtained from Swiss mice. They were collected in Hank's solution, plated on $13 \mathrm{~mm}$ round glass coverslips and allowed to adhere for $30 \mathrm{~min}$ at $37^{\circ} \mathrm{C}$ in $5 \% \mathrm{CO}_{2}$ atmosphere. Subsequently non-adherent cells were removed by washing with Hank's solution and 199 medium with $10 \%$ fetal bovine serum was added. The cells were maintained in culture for $24 \mathrm{~h}$ at $37^{\circ} \mathrm{C}$, in $5 \% \mathrm{CO}_{2}$; b) Vero (ATCC CCL-81, USA - fibroblast-like, kidney, African green monkey); c) LLCMK 2 (ATCC CCL-7, epithelial-like, kidney, Rhesus monkey); (d) HFSF (ATCC CRL 1634 fibroblast, human skin), and (e) L-6 (ATCC CRL-1458, skeletal muscle myoblast, rat) cells. All the cell lines were cultivated in $25 \mathrm{~cm}^{2}$ flasks in 199 medium plus $5 \%$ fetal bovine serum at $37^{\circ} \mathrm{C}$ in $5 \%$ $\mathrm{CO}_{2}$ atmosphere. After confluence was reached the cultures were treated with trypsin and cells were plated in 24 well plates with 13 $\mathrm{mm}$ round coverslips and kept for 24 hours in culture.

\section{Effect of drugs}

Before the experiments the cultures were washed with 199 medium without serum and incubated for 15 or $30 \mathrm{~min}$ in the presence of one of the following drugs: (a) $5 \mu \mathrm{g} / \mathrm{ml}$ of cytochalasin D (CytD) (Sigma Chemical Company-USA); (b) CytD recover experiments: the cells were treated with $5 \mu \mathrm{g} / \mathrm{ml}$ of CytD for $30 \mathrm{~min}$ and allowed to interact with trypomastigote forms of $T$. cruzi for 1 h. After that the cells were washed to remove non-adherent parasites and then incubated in 199 medium plus 5\% FBS for $1 \mathrm{~h}$ more; (c) $5 \mu \mathrm{g} / \mathrm{ml}$ of colchicine (Sigma Chemical Company-USA) ; c) $1 \mu \mathrm{M}$ of Jasplakinolide (Molecular Probes-USA) for $30 \mathrm{~min}$ at $37^{\circ} \mathrm{C}$ before $1 \mathrm{~h}$ of interaction with trypomastigotes (parasite:cell ratio of 50:1). These drugs were dissolved in dimethylsulfoxide (DMSO). As control cells were incubated in the presence of $0.1 \%$ DMSO, the same maximum concentration found in the solutions containing the drugs to be tested. After incubation the medium was removed and parasites were added as described below.

\section{Parasite-host cell interaction}

Parasites were added to the cultures so that a parasite:cell ratio of
10:1 was achieved and allowed to interact for 1 hour at $37^{\circ} \mathrm{C}$ in a $5 \% \mathrm{CO}_{2}$ atmosphere. The cultures were then washed to remove free parasites and processed for light, fluorescence and scanning electron microscopy. For light microscopy the cells were fixed with Bouin fixative and stained with Giemsa. The preparations were careful examined by bright field microscopy using an immersion lens in order to distinguish attached from internalized parasites. The percentage of cells with attached or ingested parasites and the mean number of parasites per cell were determined by randomly counting at least 200 cells in at least three independent experiments. The adhesion index was calculated by multiplying the percentage of cells with attached parasites and the mean number of parasites attached per cell The endocytic index was calculated multiplying the percentage of infected cells and the mean number of parasites per infected cell. Statistical analysis was done using F Student's test. We considered significant those differences above $10 \%(\mathrm{p}<0.05)$. For immunofluorescence microscopy the cells were fixed for $3 \mathrm{~min}$ with $0.1 \%$ glutaraldehyde (grade I), $3.7 \%$ formaldehyde and $0.5 \%$ Triton X-100 in PHEM buffer $(60 \mathrm{mM}$ Pipes, $20 \mathrm{mM}$ Hepes, $10 \mathrm{mM}$ EGTA, $5 \mathrm{mM} \mathrm{MgCl}$, $70 \mathrm{mM} \mathrm{KCl}$ ), $\mathrm{pH}$ 7.0. The cultures were then washed three times with PBS $1 \%$ albumin, incubated with $50 \mathrm{mM}$ ammonium chloride for $30 \mathrm{~min}$, and incubated for $1 \mathrm{~h}$ in the presence of phalloidin-FITC (Molecular Probes-USA) 1:100 diluted in PHEM buffer, pH 7.0. Subsequently the cultures were washed in PHEM, mounted using $\mathrm{N}$-propyl gallate, and observed in a confocal laser scanning microscope (LSM-Axiovert, Zeiss-Germany) using an $\mathrm{Ar} / \mathrm{Kr}$ laser 488 and a barrier filter LP520. For scanning electron microscopy the cells were washed and fixed in a solution containing $2.5 \%$ glutaraldehyde in PHEM buffer, $\mathrm{pH}$ 7.0, at room temperature. The cells were then washed and post-fixed in $1 \%$ osmium tetroxide for 10 minutes, washed in $0.1 \mathrm{M}$ phosphate buffer, $\mathrm{pH} 7.2$, dehydrated in acetone, critical point dryed with $\mathrm{CO}_{2}$, coated with a thin layer of gold and observed in a Zeiss DSM 962 scanning electron microscope.

\section{Results}

\section{Interaction with different cell types}

Table I shows that under the same experimental conditions there was a marked difference in the endocytic index, in the adhesion index and in the association index according to the host cell type used to interact with trypomastigote forms of T. cruzi. The endocytic index values varied from experiment to experiment. Therefore, it was very difficult to make comparisons between different sets of experiments. For this reason we prefer to consider the value found in the control of each experiment as 100 and express the values found in each treatment in relation to 100 .

\section{Effect of cytochalasin D}

Incubation of the various cell types for 15-30 $\mathrm{min}$ in the presence of $5 \mu \mathrm{g} / \mathrm{ml}$ cytochalasin D led to significant mor- 
phological changes. These included retraction of lamellopodia and long filopodia and the appearance of a large number of surface rounded projections, which could be better visualized by scanning electron microscopy (Fig.1). Figures 1a and $1 \mathrm{~b}$ show scanning electron micrographs of the process of interaction of T. cruzi with control (Fig. 1a) and cytochalasin D-treated cells (Fig. 1b). Parasites in the process of internalization could be observed in both situations. Numerous surface blebs were observed in cytochalasin D treated Vero cells (Fig. 1b). This effect was basically similar to that previously reported in other cells (Sibley et al., 2000).

Prior incubation of the host cells in the presence of Cytocalasin D induced a marked inhibition in the internalization

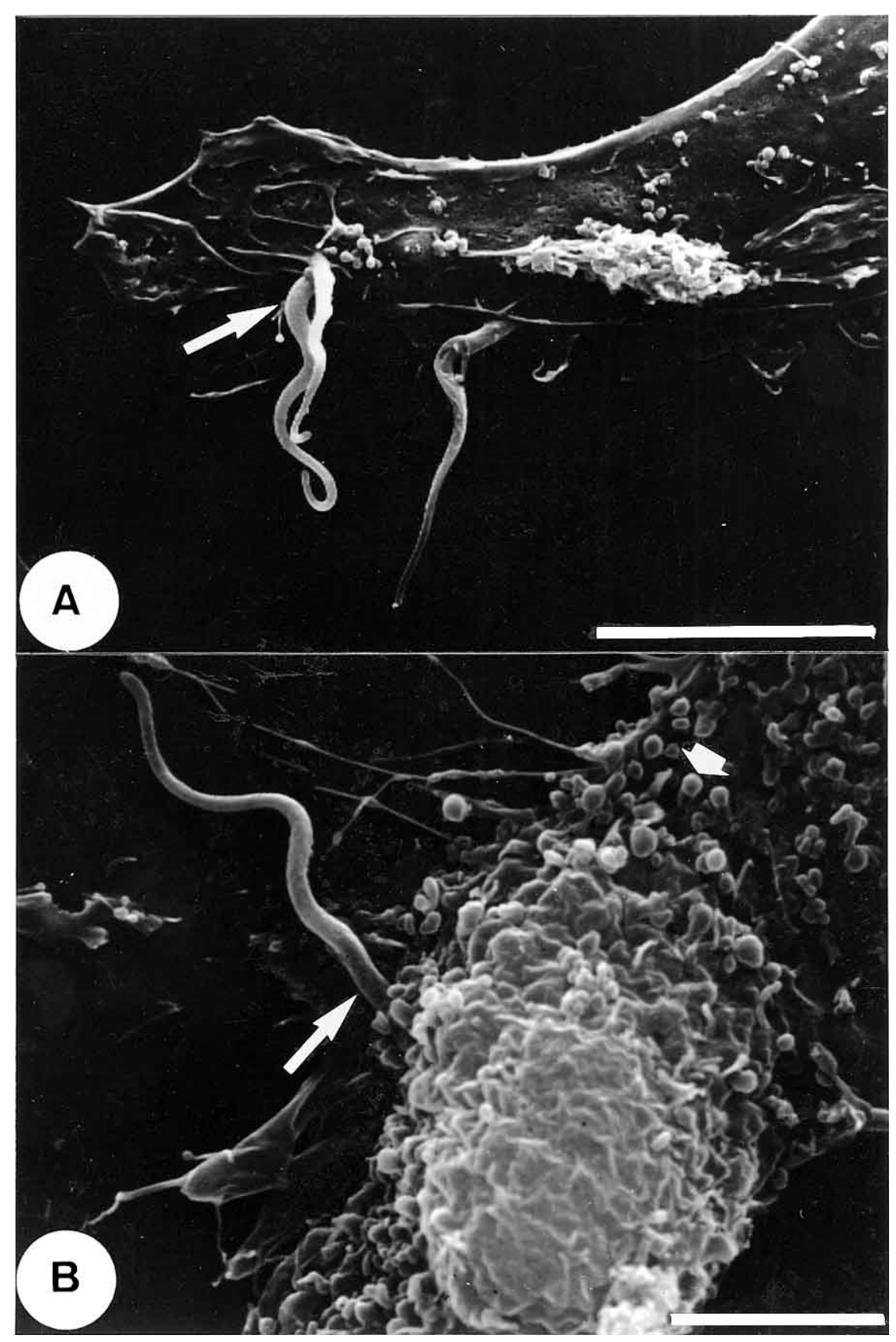

Fig. 1. Scanning electron microscopy of (a) control Vero cells showing trypomastigote forms in the process of entry (arrows), and (b) cytochalasin D-treated cells showing retraction of lamellipodia and long filopodia, and a large number of surface rounded projetions (arrowheads). Bar=10 $\mu \mathrm{m}$ (Fig. 1a); $5 \mu \mathrm{m}$ (Fig. 1b). 
of trypomastigote forms of $T$. cruzi for all cell types examined. The inhibition varied according to the cell type, reaching an inhibition level of about $93 \%$ (Table I). In contrast a marked increase in the number of parasites attached to the cell surface was observed. In some cases the number of attached parasites was ten times higher than that observed in untreated cells (Table I). No significant effect was observed if the cytochalasin D-treated cells were washed before incubation in the presence of the parasites (not shown). If cytochalasin D-treated cell were allowed to interact with trypomastigotes, washed to remove the nonadherent parasites and incubated again in 199 medium with serum for $1 \mathrm{~h}$ more, we observed a recovery of the endocytic index in all cell lines (Table I).

\section{Effect of Jasplakinolide in LLCMK 2 and macrophage cells}

Treatment of LLCMK 2 and macrophage cells for $30 \mathrm{~min}$ with $1 \mu \mathrm{M}$ of Jasplakinolide drastically affects cell morphology of both cells (data not shown). We also observed that treatment with Jasplakinolide enhanced the adhesion index, and reduced the endocytic index in cells allowed to interact with trypomastigotes of T. cruzi (Table II).

\section{Localization of actin}

We decided to use FITC-labeled phalloidin, which binds to $\mathrm{F}$ actin in the form of oligomers or filaments, to determine the localization of actin during the process of internalization of parasites by the various cell types analyzed in the present study. From the analysis of many samples we could distinguish two basic labeling patterns. The first one was characterized by the concentration of actin filaments in the region of parasite entry (Figs. 2 c,d; 3 a,b). Its important to point out that labeling was restricted to the host cell, although in some images the whole parasite was delineated. Its is well know that phalloidin binds only to actin filaments, and $T$. cruzi does not have these filaments (De Souza, 2002).This labeling pattern predominated in most of the cases, independently of the cell type. The second labeling pattern was characterized by the maintenance of the usual distribution of actin filaments in the cell independently of the presence or absence of parasites attached or in process of penetration

Table I. EFFECT OF CYTOCHALASIN D ON THE INTERACTION PROCESS OF TRYPOMASTIGOTE FORMS OF T. cruzi WITH DIFFERENT CELL TYPES

\begin{tabular}{|c|c|c|c|}
\hline \multirow[t]{2}{*}{ Cell type } & \multirow[t]{2}{*}{ Relative Adhesion Index } & \multicolumn{2}{|c|}{ Relative Endocytic Index } \\
\hline & & Drug effect ${ }^{a}$ & Drug recovery ${ }^{b}$ \\
\hline Vero contr & 100 & 100 & 100 \\
\hline Vero DMSO & 56.3 & 96.5 & \\
\hline Vero CytD & 365 & 2.8 & 33 \\
\hline LLCMK 2 contr & 100 & 100 & 100 \\
\hline LLCMK 2 DMSO & 128 & 93.3 & \\
\hline LLCMK 2 CytD & 559 & 20.3 & 27 \\
\hline L6 contr & 100 & 100 & 100 \\
\hline L6 DMSO & 77 & 83 & \\
\hline L6 CytD & 258 & 2.76 & 123.5 \\
\hline $\mathrm{M} \phi$ contr & 100 & 100 & 100 \\
\hline M $\phi$ DMSO & 160 & 91 & \\
\hline $\mathrm{M} \phi \mathrm{CytD}$ & 1020 & 27 & 150 \\
\hline HFSF contr & 100 & 100 & 100 \\
\hline HFSF DMSO & 129 & 82 & \\
\hline HFSF CytD & 525 & 3.57 & 18 \\
\hline
\end{tabular}

${ }^{a}$ Host cells were treated with $5 \mathrm{mg} / \mathrm{ml}$ of cytochalasin $\mathrm{D}$ for $30 \mathrm{~min}$, then the medium was removed and the parasites (parasite cell ratio was 10:1) were allowed to interact for $1 \mathrm{~h}$ at $37^{\circ} \mathrm{C}$. After this period the cells were processed as described in Table I.

${ }^{\mathrm{b}}$ Recover of cytochalasin treatment: effect on the interaction process. The cells were treated with $5 \mu \mathrm{g} / \mathrm{ml}$ of cytochalasin D for $30 \mathrm{~min}$ and allowed to interact with trypomastigote forms of T. cruzi for $1 \mathrm{~h}$ (using the same ratio described above). The cells were then washed to remove non-adherent parasites and incubated in 199 medium plus 5\% FBS for $1 \mathrm{~h}$ more. After that, cells were washed with PBS, fixed with Bouin and stained with Giemsa. 
Table II. EFFECT OF PRIOR TREATMENT OF LLCMK 2 AND PERITONEAL MACROPHAGES WITH 1 MM JASPLAKINOLIDE FOR 30 MIN AT $37^{\circ} \mathrm{C}$, ON THE ADHESION AND ENDOCYTIC INDEXES. INDEXES WERE NORMALIZED (\%). n=3 (FOR LLCMK 2 CELLS). FOR PERITONEAL MACROPHAGES WE USED A REPRESENTATIVE EXPERIMENT

\begin{tabular}{lcccc}
\hline Cell Type & & Control & DMSO & Jasplakinolide \\
\hline LLCMK 2 & Adhesion index & 100 & 278.04 & 1237.8 \\
& Endocytic index & 100 & 156.88 & 83.74 \\
Macrophages & Adhesion index & 100 & 145.91 & 146.94 \\
& Endocytic index & 100 & 105.94 & 14.39 \\
\hline
\end{tabular}

(Carvalho et al., 1999). In Vero cells not treated with cytochalasin D and without any contact with parasites, we could observe the distribution of stress fibers throughout the cytoplasm (Figs 2a,b).

The phalloidin labeling pattern was completely changed in cells incubated in the presence of cytochalasin D. Instead of radiating fibers, intensely labeled clumps distributed throughout the host cell cytoplasm were observed (Figs. 3 a,b). No association of the clumps with attached parasites was observed.

\section{Effect of Colchicine}

Table III shows that prior incubation of the cells in the presence of $5 \mu \mathrm{g} / \mathrm{ml}$ of colchicine, a concentration which depolymerizes microtubules but with small changes in the morphology of the cells, inhibited the endocytic index by about $70 \%$ and did not interfere or only slightly increased the number of parasites attached to the host cell surface.

\section{Discussion}

Although the process of interaction of Trypanosoma cruzi with host cells has been the subject of intense investigation in the last twenty years some important questions still remain (review in Andrews et al., 1995; Sibley et al., 2000). Significant advances have been obtained in the identification of parasite surface macromolecules involved in the interaction process with the host cells. However, despite the finding that surface glycoconjugates of the host cells also play an important role on the interaction process they have not been identified. Studies carried out using glycosylation mutants of CHO cells have clearly established that the sugar residues exposed on the cell surface significantly interfere with the attachment to and the internalization into the host cell (Ciavaglia et al., 1993). Our present observations using well established experimental conditions show a significant variation in the endocytic and adhesion indexes of T. cruzi to the various host cell lines used, thus explaining different values published in the literature.

Studies carried out by several groups have shown that involvement of host cell actin with cytochalasins interferes with the internalization of trypomastigote forms into vertebrate cells (Barbosa et al., 1995; Burleigh et al., 1995; Bur- leigh et al., 1998; Caler et al., 2000; Carvalho et al., 1999; Mortara et al., 1999; Nogueira et al., 1976; Procopio et al., 1994; Schenkman et al., 1991). In most of the studies such interference is negative, decreasing the rate of infection and increasing attachment (Barbosa et al., 1995; Meirelles et al., 1982). In other situations, however, it has been shown that cytochalasin treatment even enhances parasite penetration (Caler et al., 2000; Nogueira et al., 1976; Procopio et al., 1994; Schenkman et al., 1991; Sibley et al., 2000). We decided to re-investigate the problem using cytochalasin D in concentrations described for other systems and which proved to be highly effective at a concentration of $5 \mu \mathrm{g} / \mathrm{ml}$. This effect is completely reversed by the simple washing of the cultures. The efficiency of the drug treatment was also examined in the terms of its effect on cell morphology, as evaluated by light and scanning electron microscopy, and the effect on the distribution of host cell actin, as evaluated by the phalloidin labeling pattern. Our present observations using cell types varying from macrophages, which are typical phagocytic cells, to muscle cells in culture show that in all cases prior treatment of the cells with cytochalasin dramatically decreased parasite internalization and enhanced parasite attachment. This observation shows clearly that host cell actin plays an important role in the process of parasite internalization into the endocytic vacuole. In view of the results we obtained it is difficult to explain the results obtained in previous studies showing no effect of cytochalasin on the T. cruzi-host cell interaction. First, it is important to point out that the cytochalasin effect is rapidly reversed by a simple washing of the cultures and in this case attached parasites are readily ingested by the cells. Second, it is important to use a methodology which clearly distinguishes attached from internalized parasites. If total associated parasites are determined the drug treatment will always increase the association index. Both factors may explain the conflicting data reported in the literature. We also used Jasplakinolide, a cyclodepsipeptide isolated from the marine sponge, Jaspis johnstoni, originally used as an antifungal agent (Holzinger et al., 1997). Jasplakinolide has been shown to induce actin polymerization and bind actin filaments competitively with phalloidin (Holzinger et al., 1997). Our results show that treatment of LLCMK 2 cells with $1 \mu \mathrm{M}$ of Jasplakinolide for $30 \mathrm{~min}$, enhances adhesion 
C.T.F. Rosestolato et al.

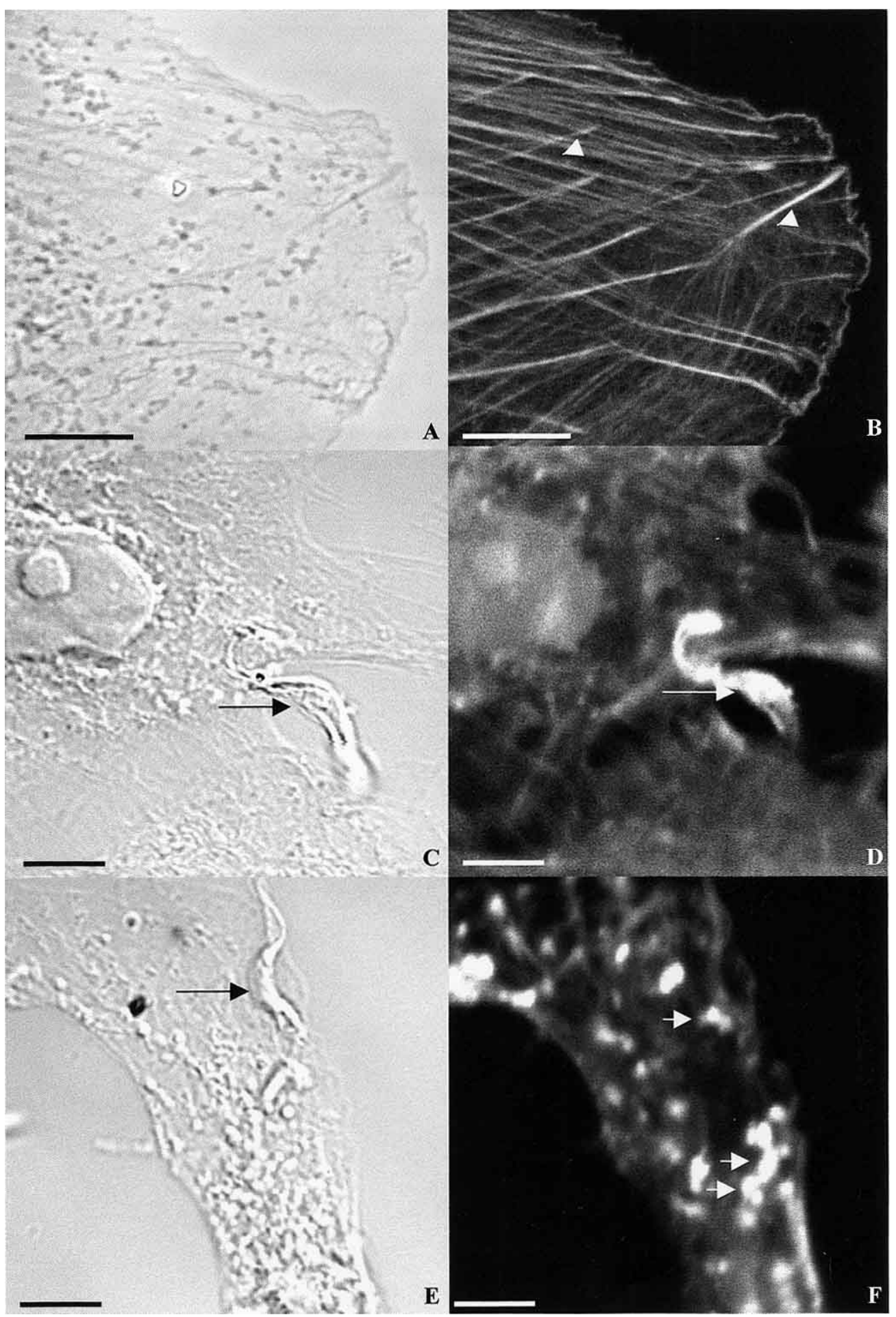

Fig. 2. Confocal Laser Scanning Microscopy images of: cytochalasin D non-treated and not infected with T. cruzi (a,b); Control (c,d) and cytochalasin Dtreated (e,f) Vero cells after $1 \mathrm{~h}$ of interaction with trypomastigote forms of T.cruzi and incubated with phalloidin-FITC. A concentration of actin filaments around the region of parasite entry is observed (arrow) in control cells (c,d). A dramatic change in the pattern of distribution of actin is observed in cells treated with cytochalasin D. Actin appears as labeled clumps distributed throughout the host cytoplasm (small arrows). $\mathbf{a}=$ phase contrast; $\mathbf{c}, \mathbf{d}=$ interferential contrast; $\mathbf{b}, \mathbf{e}, \mathbf{f}=$ fluorescence microscopy. Bar=5 $\mu \mathrm{m}(\mathrm{c}, \mathrm{d}, \mathrm{e}, \mathrm{f}) ; \mathrm{Bar}=10 \mu \mathrm{m}(\mathrm{a}, \mathrm{b})$. 


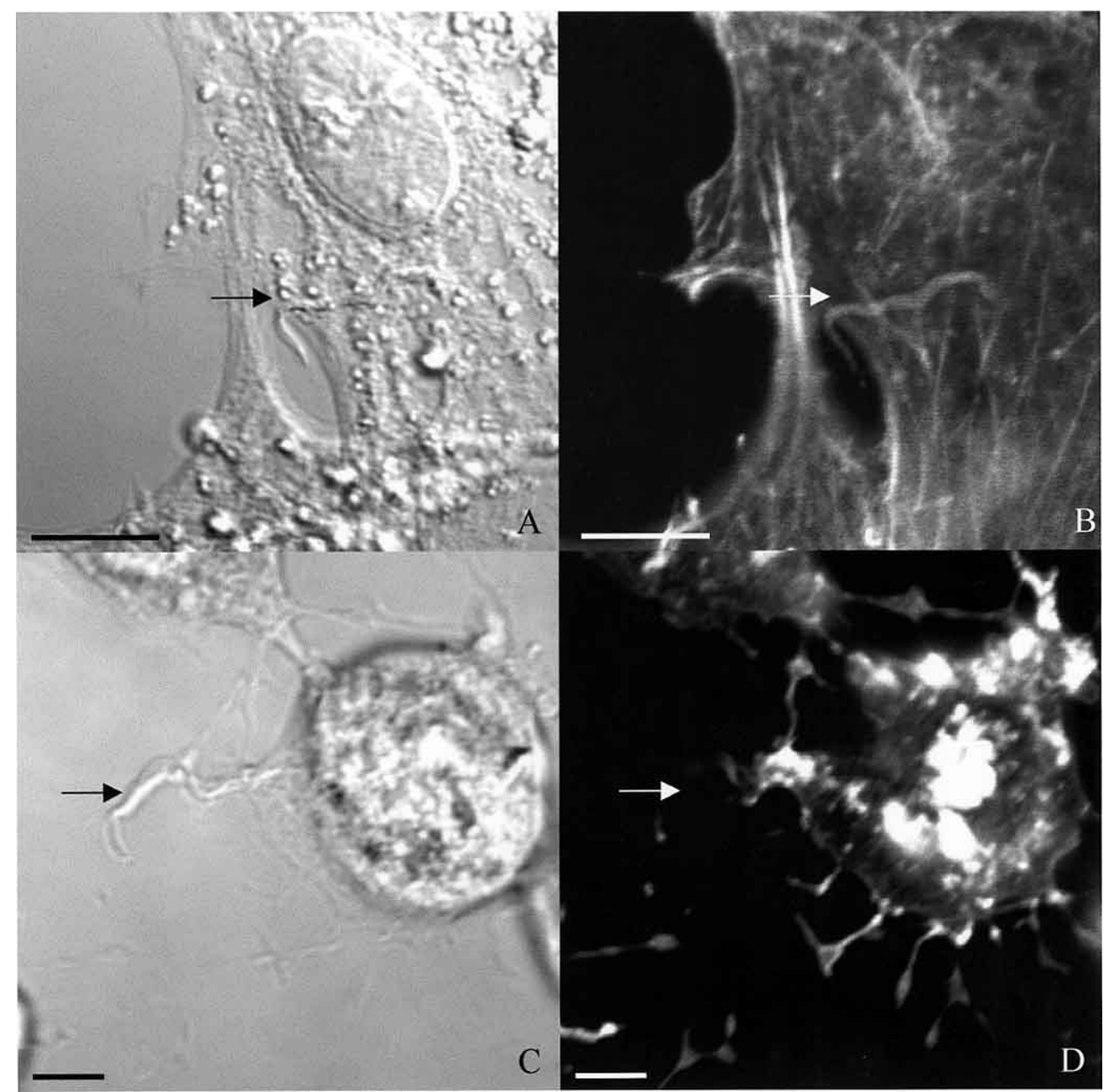

Fig. 3. Confocal laser scanning microscopy images of control (a,b) and cytochalasin D-treated (c,d) L6 cells allowed to interact with trypomastigote forms of $T$. cruzi for $1 \mathrm{~h}$. In control cells $(\mathbf{a}, \mathbf{b} ;$ Bar $=10 \mu \mathrm{m})$ we observed a normal distribuition pattern of actin filaments, and a concentration of those filaments in the site of parasite entry (arrow). A dramatic change in the distribuition pattern of actin is observed when the cells were treated with cytochalasin D (c,d; Bar=5 $\mu \mathrm{m}$ ): actin appears as labeled clumps distributed throughout the host cell cytoplasm. $\mathbf{a}, \mathbf{c}=$ interferential contrast; $\mathbf{b}, \mathbf{d}=\mathbf{f l u o r e s c e n c e}$ microscopy.

and reduces endocytic indexes of trypomastigotes of Trypanosoma cruzi.

In a typical phagocytic process actin filaments are assembled forming long pseudopodium-like surface projections which surround the particle to be ingested. Previous morphological studies have shown that such a process takes place during T. cruzi-host cell interaction (Maria et al., 1982). However, endocytic vacuoles can also be formed by a process which involves the formation of large endocytic vacuoles with the involvement of actin. Our present observations using confocal laser scanning microscopy to localize actin filaments labeled with FITC-phalloidin show that in all cells analyzed actin polymerization took place at the sites of parasite internalization as previously reported (Carvalho et al., 1999). The images obtained did not indicate that a typical phagocytic process was taking place. It is im- portant to point out that parasites also penetrate by another process with no concentration of actin filaments around the parasite (Carvalho et al., 1999 and ours results in this paper). Taken togehter the available results suggest that $T$. cruzi may penetrate into host cells by three mechanisms: (a) a typical phagocytic process involving the formation of filopodium-like projections which is dependent on actin filament assembly; (b) an endocytic process which does not depend on the formation of filopodium-like extensions but is dependent of actin filament assembly for parasite internalization, and (c) an endocytic process which does not depend on actin filament assembly.

Our present observations also suggest that host cell cytoplasmic microtubules play some role in the process of parasite internalization since their disruption by colchicine treatment inhibited parasite internalization. Previous studies 
Table III. EFFECT OF COLCHICINE TREATMENT ON THE INTERACTION PROCESS OF TRYPOMASTIGOTES OF T. CRUZI WITH DIFFERENT HOST CELLS. THE CELLS WERE INCUBATED FOR $30 \mathrm{MIN}$ AT $37^{\circ} \mathrm{C}$ WITH $5 \mu \mathrm{g} / \mathrm{ml}$ OF COLCHICINE, WASHED AND ALLOWED TO INTERACT WITH TRYPOMASTIGOTE FORMS FOR $1 \mathrm{H} \mathrm{AT} 37^{\circ} \mathrm{C}$

\begin{tabular}{lcc}
\hline Cell type & $\begin{array}{c}\text { Relative Adhesion } \\
\text { Index }\end{array}$ & $\begin{array}{c}\text { Relative Endocytic } \\
\text { Index }\end{array}$ \\
\hline Vero Contr. & $100(1.0)$ & $100(13.6)$ \\
Vero Colch. & 180 & 24.2 \\
LLCMK 2 Contr. & $100(1.9)$ & $100(22.2)$ \\
LLCMK 2 Colch. & 115 & 25.2 \\
L6 Contr. & $100(1.4)$ & $100(2.4)$ \\
L6 Colch. & 100 & 12.5 \\
\hline
\end{tabular}

have shown that $T$. cruzi penetration is also dependent on the migration of host cell lysosomes, in a microtubuledependent process, to the site of parasite internalization (Schenkman et al., 1994).

Acknowledgments. The authors thank Miss Rosemary C. Maciel, Darli G Keller, Márcia Adriana S. C. Dutra, Giovana Alves de Moraes for technical support. This work has been supported by Programa de Núcleos de Excelência (PRONEX), Conselho Nacional de Desenvolvimento Científico e Tecnológico $(\mathrm{CNPq})$, Fundação Carlos Chagas Filho de Amparo à Pesquisa do Estado do Rio de Janeiro (FAPERJ), and Fundação Estadual do Norte Fluminense (FENORTE).

\section{References}

Andrews, N.W. 1995. Lysosome recruitment during host cell invasion by Trypanosoma cruzi. Trend. Cell Biol., 5: 133-137.

Araujo-Jorge, T.C., Barbosa, H.S., and Meirelles, M.N.L. 1992. Trypanosoma cruzi recognition by macrophages and muscle cells: Perspectives after a 15 year study. Mem. Inst. Oswaldo Cruz, 87: 43-56.

Barbosa, H.S. and Meirelles, M.N.L. 1995. Evidence of participation of cytoskeleton of heart muscle cells during invasion of Trypanosoma cruzi. Cell Struct. Funct., 20: 275-284.

Brener, Z. 1973. Biology of Trypanosoma cruzi. Ann. Rev. Microbiol., 27: 347-382.

Burleigh, B.A. and Andrews, N.W. 1995. The mechanisms of Trypanosoma cruzi invasion of mammalian cells. Ann. Rev. Microbiol., 49: $175-200$

Burleigh, B.A. and Andrews, N.W. 1998. Signaling and host cell invasion by Trypanosoma cruzi. Curr. Opin. Microbiol., 1: 461-465.

Caler, E.V., Morty, R.E., Burleigh, B.A., and Andrews, N.W. 2000. Dual role of signaling pathways leading to $\mathrm{Ca}^{2+}$ and cyclic AMP elevation in host cell invasion by Trypanosoma cruzi. Infect. Immun., 68: 66026610 .

Carvalho, T.M.U. and De Souza, W. 1989. Early events related with the behavior of Trypanosoma cruzi within an endocytic vacuole in mouse peritoneal macrophage. Cell Struct. Funct., 14: 383-392.

Carvalho, T.M.U., Ferreira, A.G., Coimbra, E.S., Rosestolato, C.T.F., and De Souza, W. 1999. Distribution of cytoskeletal structures and organelles of host cell during evolution of the intracellular parasitism by
Trypanosoma cruzi. J. Submicros. Cytol. Pathol., 31: 325-333.

Ciavaglia, M.C., Carvalho, T.M.U., and De Souza, W. 1993. Interaction of Trypanosoma cruzi with cells with altered glycosylation patterns. Biochem. Biophys. Res. Commun., 193: 718-721.

Cooper, J.A. 1987. Effects of cytochalasin and phalloidin on actin. J. Cell Biol., 105: 1473-1478.

De Souza, W. 2002. Basic Bilogy of Trypanosoma cruzi. Current Pharmaceutical Drugs, 8: 211-231.

DoCampo, R. and Moreno, S.N.J. 1996. The role of calcium the process of cell invasion by intracellular parasites. Parasitology Today, 12: 61-65.

Holzinger, A. and Meindl, U. 1997. Jasplakinolide, a novel actin targeting peptide, inhibts growth and induces actin filament polymerization in the green alga Micrasterias. Cell Mot. Cytosk., 38: 365-372.

Kipnis, T.L., Calich, V.L.G., and Dias da Silva, W. 1979. Active entry of bloodstream forms of Trypanosoma cruzi into macrophages Parasitology, 78: 89-98.

Ley, V., Robbins, E.S., Nussenzweig, V., and Andrews, N.W. 1990. The exit of Trypanosoma cruzi from the phagosome is inhibited by raising the $\mathrm{pH}$ of acidic compartments. J. Exp. Med., 171: 401-413.

Maria, T.A., Alcantara, A. and Brener, Z. 1982. Ultrastructural studies on the in vitro interaction of Trypanosoma cruzi bloodstream forms and mouse peritoneal macrophages. Acta Trop., 39: 99-109.

Meirelles, M.N.L., Chiari, E., and De Souza, W. 1982. Interaction of bloodstream, tissue culture-derived trypomastigotes of Trypanosoma cruzi with macrophages. Acta Trop., 39: 195-203.

Mortara, R.A., Procopio, D.A., Barros, H.C., Verbisck, N.V., Andreoli, W.K., Silva, R.B.S., and Da Silva, S. 1999. Features of host cell invasion by different infective forms of Trypanosoma cruzi. Mem. Inst Oswaldo Cruz, 94 (suppl. II): 135-137.

Nogueira, N. and Cohn, Z. 1976. Trypanosoma cruzi: Mechanism of entry and intracellular fate in mammalian cells. J. Exp. Med., 143: 1402-1420.

Procopio, D.O. and Mortara, R.A. 1994. The mechanisms used by two developmental forms of Trypanosoma cruzi to invade mammalian cells are different and may be dependent on host cells. Mem. Inst. Oswaldo Cruz, 89: 61

Schenkman, S., Robins, E.S., and Nussenzweig, V. 1991. Attachment of Trypanosoma cruzi to mammalian cells requires parasite energy, and invasion can be indepentent of target cell cytoskeleton. Infect. Immun., 59: 645-654.

Schenkman, S. and Mortara, R.A. 1992. HeLa cells extend and internalize pseudopia during active invasion by Trypanosoma cruzi. J. Cell Sci., 101: 895-905.

Schenkman, S. Eichinger, D., Pereira, M.E.A., and Nussenzweig, V. 1994. Structural and functional properties of Trypanosoma cruzi Transsialidase. Ann. Rev. Microbiol., 48: 499-523.

Sibley, L.D. and Andrews, N.A. 2000. Cell invasion by un-palatable parasites. Traffic, 1: 100-106.

Tardieux, I., Nathanson, P., and Andrews, N.W. 1994. Role in host cell invasion of Trypanosoma cruzi-induced cytosolic-free calcium transients. J. Exp. Med., 179: 1017-1022.

Temmink, J.H.M. and Spiele, H. 1981. Effect of vinblastine and Cytochalasin B on the cytoskeletal domains in 3T3 cells. J. Cell Sci., 48: 5573

Vieira, M.C.F., Carvalho, T.M.U., and De Souza, W. 1994. Effect of protein kinase inhibitors on the invasion process of macrophages by Trypanosoma cruzi. Biochem. Biophys. Res. Comm., 203: 967-971.

(Received for publication, September 25, 2001

and in revised form, January 30, 2002) 